\title{
PENGARUH PEMUPUKAN NITROGEN DAN SISTEM OLAH TANAH JANGKA PANJANG TERHADAP PERTUMBUHAN DAN PRODUKSI PADI GOGO (Oryza sativa L.) TAHUN KE-27 DI LAHAN POLITEKNIK NEGERI LAMPUNG
}

\author{
Agnesi Deria Hepriyani, Kuswanta F. Hidayat \& Muhajir Utomo \\ Jurusan Agroteknologi Fakultas Pertanian Universitas Lampung \\ J1. Prof. Dr. Soemantri Brodjonegoro, No. 1 Bandar Lampung 35141 \\ Email: agnesideriahepriyani@yahoo.com
}

\begin{abstract}
ABSTRAK
Padi gogo merupakan salah satu tanaman pangan yang berpotensi untuk dikembangkan. Pada tahun-tahun mendatang peranan padi gogo dalam penyediaan beras nasional menjadi semakin penting. Hal ini disebabkan karena semakin berkurangnya areal persawahan, sedangkan tingkat pertumbuhan penduduk cukup tinggi. Salah satu upaya dalam meningkatkan pertumbuhan dan produksi padi gogo adalah dengan sistem olah tanah dan pemupukan nitrogen. Tujuan penelitian adalah untuk mengetahui pengaruh pemupukan nitrogen jangka panjang dengan berbagai dosis terhadap pertumbuhan dan produksi padi gogo, mengetahui pengaruh sistem olah tanah jangka panjang terhadap pertumbuhan dan produksi padi gogo, dan mengetahui pengaruh interaksi antara sistem olah tanah dan pemupukan nitrogen jangka panjang dengan berbagai dosis terhadap pertumbuhan dan produksi padi gogo. Penelitian dilakukan di lahan Politeknik Negeri Lampung. Analisis tanaman dilakukan di Laboratorium Ilmu Tanaman Jurusan Agroteknologi Fakultas Pertanian Universitas Lampung. Penelitian dilaksanakan pada bulan Oktober 2014 sampai dengan Maret 2015. Penelitian dilakukan menggunakan Rancangan Acak Kelompok (RAK) yang disusun secara faktorial dengan 4 ulangan. Hasil penelitian menunjukkan bahwa pemupukan nitrogen dengan dosis $100 \mathrm{~kg} \mathrm{~N}$ $\mathrm{ha}^{-1}$ meningkatkan pertumbuhan dibandingkan tanpa pemupukan nitrogen tetapi tidak berbeda dengan pemupukan $50 \mathrm{~kg} \mathrm{~N}$ $\mathrm{ha}^{-1}$. Pemupukan nitrogen dengan dosis $100 \mathrm{~kg} \mathrm{~N} \mathrm{ha}^{-1}$ meningkatkan produksi padi gogo lebih tinggi dibandingkan tanpa pemupukan nitrogen tetapi tidak berbeda dengan pemupukan $50 \mathrm{~kg} \mathrm{~N} \mathrm{ha}^{-1}$. Sistem Olah Tanah Intensif mampu meningkatkan tinggi tanaman, dan bobot kering berangkasan lebih tinggi dibandingkan dengan Olah Tanah Konservasi, sedangkan sistem olah tidak memberikan pengaruh terhadap komponen hasil. Interaksi antara pemupukkan nitrogen dan sistem olah tanah terjadi pada variabel pengamatan tinggi tanaman, sedangkan terhadap komponen hasil tidak berpengaruh.
\end{abstract}

Kata Kunci: nitrogen, padi gogo, pemupukan, pertumbuhan, produksi, sistem olah tanah.

\section{PENDAHULUAN}

Padi (Oryza sativa L.) merupakan tanaman terpenting di Indonesia, yang permintaanya mengalami peningkatan setiap tahunnya (Wibowo, 2000). Menurut Abdullah (2003), peningkatan produksi padi perlu terus dilakukan sesuai dengan pertumbuhan penduduk Indonesia. Kebutuhan beras untuk tahun 2025 diperkirakan mencapai 78 juta ton GKG. $95 \%$ penduduk Indonesia mengonsumsi beras sebagai makanan pokok sehari-hari.

Tantangan pengadaan pangan nasional kedepan akan semakin berat karena banyak lahan irigasi subur yang terkonversi untuk kepentingan non pertanian dan jumlah penduduk yang terus meningkat setiap tahunnya. Dengan semakin berkurangnya luas lahan sawah karena pengalihan fungsi, maka lahan kering untuk pengembangan pertanian harus segera dimanfaatkan
(Toha, 2002). Pengolahan tanah yang tepat agar kualitas lahan dapat tetap terjaga dapat dilakukan melalui penerapan sistem olah tanah konservasi (OTK). Teknologi OTK adalah suatu sistem persiapan lahan yang bertujuan untuk menyiapkan lahan agar tanaman dapat tumbuh dan berproduksi optimum, dengan tetap memperhatikan konservasi tanah dan air (Utomo, 1995). Untuk mempertahankan kualitas tanah diperlukan pengolahan tanah yang tidak merusak tanah.

Salah satu usaha tersebut adalah pengolahan tanah secara konservasi meliputi olah tanah minimum (OTM) dan tanpa olah tanah (TOT). Sistem OTM dan TOT pada prinsipnya hanya mengubah cara penyiapan lahan, sedangkan kegiatan budidaya tetap dilakukan seperti biasa. Selain dengan melakukan olah tanah konservasi, usaha untuk meningkatkan produksi tanaman pangan juga dapat dilakukan dengan pemupukan. Pemupukan merupakan suatu tindakan pemberian unsur 
hara ke tanah atau tanaman sesuai yang dibutuhkan untuk pertumbuhan normal tanaman (Pulung, 2005).

Pasokan nitrogen $(\mathrm{N})$ dalam tanah merupakan faktor yang paling penting kaitannya dengan pemeliharaan atau peningkatan kesuburan tanah yang akan mempengaruhi pertumbuhan tanaman. Menurut Buckman dan Brady (1992), nitrogen yang pada umumnya diberikan sebagai pupuk, dapat memberikan efek yang menguntungkan bagi tanaman, sebagai contoh nitrogen dapat menstimulir pertumbuhan di atas tanah yaitu batang, dan memberikan warna hijau pada daun serta memperbesar butir-butir dan protein tanaman serealia. Pemupukan ini bertujuan untuk menambah unsur hara yang dibutuhkan tanaman untuk dapat meningkatkan pertumbuhan, meningkatkan produksi, dan mutu hasil produksi serta mutu hasil tanaman (Sanchez, 1992).

Tujuan penelitian adalah untuk mengetahui pengaruh pemupukan nitrogen jangka panjang dengan berbagai dosis terhadap pertumbuhan dan produksi padi gogo, mengetahui pengaruh sistem olah tanah jangka panjang terhadap pertumbuhan dan produksi padi gogo., dan mengetahui pengaruh interaksi antara sistem olah tanah dan pemupukan nitrogen jangka panjang dengan berbagai dosis terhadap pertumbuhan dan produksi padi gogo.

\section{BAHAN DAN METODE}

Penelitian ini merupakan penelitian jangka panjang dilaksanakan di lahan Politeknik Negeri Lampung yang berada pada $105^{\circ} 13^{\prime} 45,5^{\prime \prime}$ - $105^{\circ} 13^{\prime} 48,0^{\prime \prime}$ BT dan $05^{\circ} 21^{\prime} 19,6^{\prime \prime}-05^{\circ} 21^{\prime} 19,7^{\prime \prime} \mathrm{LS}$, dengan elevasi $122 \mathrm{~m}$ dari permukaan laut (Utomo, 2012), dan Laboratorium Ilmu Tanaman Jurusan Agroteknologi Fakultas Pertanian Universitas Lampung. Penelitian ini dilaksanakan mulai bulan Oktober 2014 sampai Maret 2015.

Bahan-bahan yang digunakan pada penelitian ini adalah benih padi gogo Varietas Inpago 8 , herbisida
Round-Up dan Lindomin, pupuk Urea dengan 3 dosis berbeda yaitu $0 \mathrm{~kg} \mathrm{~N} \mathrm{ha}^{-1}, 50 \mathrm{~kg} \mathrm{~N} \mathrm{ha}^{-1}, 100 \mathrm{~kg} \mathrm{~N} \mathrm{ha}^{-1}$, SP-36 dengan dosis $150 \mathrm{~kg} \mathrm{ha}^{-1}$, dan $\mathrm{KCl}$ dengan dosis $100 \mathrm{~kg} \mathrm{ha}^{-1}$. Alat-alat yang digunakan dalam penelitian ini adalah cangkul, koret, timbangan, tali plastik, alat penugal, meteran, alat tulis, dan kamera.

Penelitian ini menggunakan Rancangan Faktorial (3x3) dalam Rancangan Kelompok Teracak Sempurna (RKTS) dengan 4 kali ulangan. Sebagai faktor pertama adalah sistem olah tanah (T), yaitu tanpa olah tanah (T0), olah tanah minimum (T1), dan olah tanah intensif (T2). Pengolahan tanah dilakukan hanya pada plot Olah Tanah Intensif (OTI) menggunakan alat koret dan cangkul sisa tanaman atau gulma dibuang dari petak percobaan. Untuk Olah Tanah Minimum (OTM) tanah diolah seperlunya saja gulma dibersihkan dengan menggunakan koret, kemudian sisa tanaman dan gulma digunakan sebagai mulsa. Sedangkan pada petak tanpa olah tanah (TOT) tanah tidak diolah sama sekali, gulma yang tumbuh dikendalikan dengan menggunakan herbisida Roundup dengan dosis 3 - 5 liter ha ${ }^{-1}$ dan Lindomin dengan dosis 0,5 - 1 liter ha-1 pada dua minggu sebelum tanam dan gulmanya digunakan sebagai mulsa. Sebagai faktor kedua adalah dosis pupuk nitrogen $(\mathrm{N})$ dengan tiga taraf, yaitu $0 \mathrm{~kg} \mathrm{~N}^{-1}(\mathrm{~N} 0), 50 \mathrm{~kg} \mathrm{~N}^{-1}(\mathrm{~N} 1)$, dan $100 \mathrm{~kg} \mathrm{~N} \mathrm{ha}^{-1}$ (N2). Petak percobaan yang digunakan pada penelitian ini berukuran $4 \mathrm{~m} \times 6 \mathrm{~m}$. Data dianalisis dengan analisis ragam dan dilanjutkan dengan uji Beda Nyata Terkecil (BNT) pada taraf nyata $=5 \%$ untuk melihat perbedaan antar perlakuan.

\section{HASIL DAN PEMBAHASAN}

Pada Tabel 1 hasil penelitian menunjukkan bahwa pemberian dosis pupuk nitrogen $100 \mathrm{~kg} \mathrm{~N} \mathrm{ha}^{-1}$ mempunyai tinggi tanaman tertinggi dibandingkan dengan tanpa pemupukan nitrogen, tetapi tidak berbeda nyata dibandingkan $50 \mathrm{~kg} \mathrm{~N}$ ha $^{-1}$ pada semua pengamatan. Sistem olah tanah intensif meningkatkan

Tabel 1. Pengaruh pemupukan nitrogen jangka panjang terhadap tinggi tanaman.

\begin{tabular}{cccccc}
\hline \multirow{2}{*}{$\begin{array}{c}\text { Pemupukan } \\
\text { Nitrogen }\left(\mathrm{kg} \mathrm{N} \mathrm{ha}^{-1}\right)\end{array}$} & $4 \mathrm{MST}$ & $5 \mathrm{MST}$ & $6 \mathrm{MST}$ & $7 \mathrm{MST}$ & $8 \mathrm{MST}$ \\
\cline { 2 - 6 } & $34,4 \mathrm{~b}$ & $42,9 \mathrm{~b}$ & $53,1 \mathrm{~b}$ & $59,1 \mathrm{~b}$ & $62,6 \mathrm{~b}$ \\
0 & $37,4 \mathrm{a}$ & $45,5 \mathrm{a}$ & $54,6 \mathrm{ab}$ & $60,8 \mathrm{ab}$ & $65,2 \mathrm{ab}$ \\
50 & $38,5 \mathrm{a}$ & $46,8 \mathrm{a}$ & $55,9 \mathrm{a}$ & $63,0 \mathrm{a}$ & $67,7 \mathrm{a}$ \\
\hline 100 & 2,15 & 1,83 & 2,08 & 2,44 & 2,80 \\
\hline BNT $_{(0,05)}$ & &
\end{tabular}

Keterangan: Angka yang diikuti oleh huruf yang sama tidak berbeda nyata dengan uji BNT pada taraf nyata $5 \% ;$ MST = minggu setelah tanam. 
tinggi tanaman dibandingkan dengan olah tanah minimum dan tanpa olah tanah (Tabel 2). Sedangkan pengaruh interaksi antara pemupukan nitrogen dengan dosis 100 $\mathrm{kg} \mathrm{N} \mathrm{ha}^{-1}$ dan olah tanah intensif memiliki tinggi tanaman tertinggi (Tabel 3 dan Tabel 4). Perlakuan pemberian pupuk dengan dosis $100 \mathrm{~kg} \mathrm{~N} \mathrm{ha}^{-1}$ mampu mempengaruhi dan meningkatkan jumlah anakan per rumpun lebih tinggi dibandingkan dengan dosis $50 \mathrm{~kg} \mathrm{~N} \mathrm{ha}^{-1}$. Pemupukan

Tabel 2. Pengaruh sistem olah tanah terhadap tinggi tanaman.

\begin{tabular}{lcccc}
\hline \multirow{2}{*}{ Sistem Olah Tanah } & \multicolumn{4}{c}{ Tinggi Tanaman $(\mathrm{cm})$} \\
\cline { 2 - 5 } & 5 MST & 6 MST & 7 MST & 8 MST \\
\hline Olah Tanah Intensif & $46,5 \mathrm{a}$ & $57,2 \mathrm{a}$ & $64,1 \mathrm{a}$ & $68,3 \mathrm{a}$ \\
Olah Tanah & & & & $60,9 \mathrm{~b}$ \\
Minimum & $45,0 \mathrm{ab}$ & $54,2 \mathrm{~b}$ & $65,1 \mathrm{~b}$ \\
Tanpa Olah Tanah & $43,8 \mathrm{~b}$ & $52,3 \mathrm{~b}$ & $57,7 \mathrm{c}$ & $62,1 \mathrm{c}$ \\
\hline BNT $_{(0,05)}$ & 1,83 & 2,08 & 2,44 & 2,81 \\
\hline
\end{tabular}

Keterangan: Angka yang diikuti oleh huruf yang sama tidak berbeda nyata dengan uji BNT pada taraf nyata $5 \%$; MST = minggu setelah tanam.

Tabel 3. Pengaruh interaksi pemupukan nitrogen dan sistem olah tanah jangka panjang terhadap tinggi tanaman pada enam minggu setelah tanam.

\begin{tabular}{cccc}
\hline \multirow{2}{*}{$\begin{array}{c}\text { Pemupukan } \\
\text { Nitrogen }\left(\mathrm{kg} \mathrm{N} \mathrm{ha}^{-1}\right)\end{array}$} & \multicolumn{3}{c}{ Tinggi Tanaman pada 6 MST $(\mathrm{cm})$} \\
\cline { 2 - 4 } & OTI & OTM & TOT \\
\hline 0 & $56,3 \mathrm{a}$ & $53,7 \mathrm{a}$ & $49,4 \mathrm{~b}$ \\
50 & $\mathrm{~B}$ & $\mathrm{~A}$ & $\mathrm{~B}$ \\
& $54,9 \mathrm{a}$ & $54,3 \mathrm{a}$ & $54,7 \mathrm{a}$ \\
100 & $\mathrm{~B}$ & $\mathrm{~A}$ & $\mathrm{AB}$ \\
& $60,3 \mathrm{a}$ & $54,5 \mathrm{~b}$ & $52,9 \mathrm{~b}$ \\
BNT $_{(0,05)}$ & $\mathrm{A}$ & $\mathrm{A}$ & $\mathrm{A}$ \\
\hline
\end{tabular}

Keterangan: Angka yang diikuti oleh huruf yang sama tidak berbeda nyata dengan uji BNT pada taraf nyata $5 \%$, horizontal untuk perbandingan huruf kecil dan vertikal untuk perbandingan huruf besar. OTI = Olah Tanah Intensif, OTM = Olah Tanah Minimum, TOT = Tanpa Olah Tanah

Tabel 4. Pengaruh interaksi pemupukan nitrogen dan sistem olah tanah jangka panjang terhadap tinggi tanaman pada 7 MST

\begin{tabular}{cccc}
\hline Pemupukan & \multicolumn{3}{c}{ Tinggi Tanaman pada 7 MST $(\mathrm{cm})$} \\
\cline { 2 - 4 } Nitrogen $\left(\mathrm{kg} \mathrm{N} \mathrm{ha}^{-1}\right)$ & OTI & OTM & TOT \\
\hline 0 & $63,0 \mathrm{a}$ & $59,8 \mathrm{a}$ & $54,4 \mathrm{~b}$ \\
& $\mathrm{~B}$ & $\mathrm{~A}$ & $\mathrm{~B}$ \\
50 & $60,9 \mathrm{a}$ & $61,2 \mathrm{a}$ & $60,3 \mathrm{a}$ \\
& $\mathrm{B}$ & $\mathrm{A}$ & $\mathrm{A}$ \\
100 & $68,4 \mathrm{a}$ & $61,8 \mathrm{~b}$ & $58,6 \mathrm{~b}$ \\
& $\mathrm{~A}$ & $\mathrm{~A}$ & $\mathrm{~A}$ \\
\hline BNT $_{(0,05)}$ & 4,23 & & \\
\hline
\end{tabular}

Keterangan: Angka yang diikuti oleh huruf yang sama tidak berbeda nyata dengan uji BNT pada taraf nyata 5\%, horizontal untuk perbandingan huruf kecil dan vertikal untuk perbandingan huruf besar. OTI = Olah Tanah Intensif, OTM = Olah Tanah Minimum, TOT = Tanpa Olah Tanah 
nitrogen dengan dosis $50 \mathrm{~kg} \mathrm{~N} \mathrm{ha-1}$ mampu mempengaruhi dan meningkatkan jumlah anakan per rumpun dibandingkan dengan $0 \mathrm{~kg} \mathrm{~N}^{-1}$ (Tabel 5). Sedangkan pemberian pupuk dengan dosis $100 \mathrm{~kg} \mathrm{~N}$ ha $^{-1}$ mampu mempengaruhi dan meningkatkan jumlah anakan maksimum per rumpun lebih tinggi dibandingkan dengan dosis $0 \mathrm{~kg} \mathrm{~N} \mathrm{ha}^{-1}$ tetapi tidak berbeda dengan

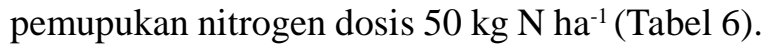

Tabel 6 menunjukkan bahwa perlakuan pemberian pupuk dengan dosis $100 \mathrm{~kg} \mathrm{~N} \mathrm{ha}^{-1}$ mampu mempengaruhi dan meningkatkan bobot kering berangkasan lebih tinggi dibandingkan dengan dosis $0 \mathrm{~kg} \mathrm{~N}$ ha ${ }^{-1}$ tetapi tidak berbeda dengan pemupukan nitrogen dosis $50 \mathrm{~kg} \mathrm{~N}$ ha $^{-1}$. Sedangkan pada Tabel 7 perlakuan sistem olah tanah intensif mampu mempengaruhi dan meningkatkan bobot kering berangkasan per $\mathrm{m}^{2}$ lebih tinggi dibandingkan dengan tanpa olah tanah tetapi tidak berbeda dengan olah tanah minimum.

Perlakuan pemberian pupuk dengan dosis $100 \mathrm{~kg}$ $\mathrm{N} \mathrm{ha}^{-1}$ mampu mempengaruhi dan meningkatkan jumlah anakkan produktif lebih tinggi dibandingkan dengan dosis $0 \mathrm{~kg} \mathrm{~N}$ ha $^{-1}$ tetapi tidak berbeda dengan pemupukan nitrogen dosis $50 \mathrm{~kg} \mathrm{~N} \mathrm{ha}^{-1}$. Untuk jumlah gabah total per rumpun pemupukan nitrogen dosis $100 \mathrm{~kg} \mathrm{~N} \mathrm{ha}^{-1}$ mampu mempengaruhi jumlah gabah total per rumpun lebih baik dibandingkan dengan $50 \mathrm{~kg} \mathrm{~N} \mathrm{ha}^{-1}$, sedangkan pemupukan nitrogen dosis $50 \mathrm{~kg} \mathrm{~N} \mathrm{ha-1} \mathrm{lebih} \mathrm{baik}$ dibandingkan $0 \mathrm{~kg} \mathrm{~N} \mathrm{ha}^{-1}$. Pada jumlah gabah isi per rumpun pemupukan nitrogen dosis $100 \mathrm{~kg} \mathrm{~N} \mathrm{ha}^{-1}$ mampu mempengaruhi jumlah gabah isi per rumpun lebih baik dibandingkan dengan $50 \mathrm{~kg} \mathrm{~N} \mathrm{ha}^{-1}$, sedangkan pemupukan nitrogen dosis $50 \mathrm{~kg} \mathrm{~N} \mathrm{ha}^{-1}$ tidak berbeda dengan $0 \mathrm{~kg} \mathrm{~N}$ ha $^{-1}$ (Tabel 8).

Pada jumlah gabah hampa per rumpun pemupukan nitrogen dosis $100 \mathrm{~kg} \mathrm{~N} \mathrm{ha}{ }^{-1}$ mampu mempengaruhi jumlah gabah hampa per rumpun lebih baik dibandingkan dengan $50 \mathrm{~kg} \mathrm{~N}$ ha $^{-1}$, sedangkan pemupukan nitrogen dosis $50 \mathrm{~kg} \mathrm{~N}^{-1} \mathrm{ha}^{-1}$ lebih baik dibandingkan dengan $0 \mathrm{~kg} \mathrm{~N} \mathrm{ha}^{-1}$. Sedangkan untuk bobot 100 butir menunjukkan bahwa pemupukan nitrogen dosis $100 \mathrm{~kg} \mathrm{~N}^{-1}$ mampu mempengaruhi bobot 100 butir lebih baik dibandingkan dengan $50 \mathrm{~kg} \mathrm{~N} \mathrm{ha}^{-1}$, tetapi pemupukan nitrogen dosis $100 \mathrm{~kg} \mathrm{~N} \mathrm{ha}^{-1}$ tidak berbeda dengan $0 \mathrm{~kg} \mathrm{~N} \mathrm{ha}^{-1}$. Pada variabel pengamatan bobot gabah per rumpun, pemupukan nitrogen dosis $100 \mathrm{~kg} \mathrm{~N}$ $\mathrm{ha}^{-1}$ mampu mempengaruhi bobot gabah per rumpun lebih baik dibandingkan dengan $50 \mathrm{~kg} \mathrm{~N}$ ha ${ }^{-1}$, tetapi pemupukan nitrogen dosis $50 \mathrm{~kg} \mathrm{~N}^{-1}$ tidak berbeda dengan $0 \mathrm{~kg} \mathrm{~N}^{-1}$ (Tabel 9). Tabel 10 menunjukkan bahwa pemupukan nitrogen dosis $100 \mathrm{~kg} \mathrm{~N} \mathrm{ha}^{-1}$ mampu mempengaruhi produksi gabah per petak panen lebih baik dibandingkan dengan $50 \mathrm{~kg} \mathrm{~N} \mathrm{ha-1}$, tetapi

Tabel 5. Pengaruh pemupukan nitrogen jangka panjang terhadap jumlah anakan per rumpun.

\begin{tabular}{ccccc}
\hline \multirow{2}{*}{$\begin{array}{c}\text { Pemupukan Nitrogen } \\
\left(\mathrm{kg} \mathrm{N} \mathrm{ha}^{-1}\right)\end{array}$} & $4 \mathrm{MST}$ & $5 \mathrm{MST}$ & $6 \mathrm{MST}$ & $7 \mathrm{MST}$ \\
\cline { 2 - 5 } & $1,3 \mathrm{~b}$ & $1,9 \mathrm{~b}$ & $2,9 \mathrm{~b}$ & $3,3 \mathrm{~b}$ \\
50 & $1,7 \mathrm{a}$ & $3,2 \mathrm{a}$ & $4,0 \mathrm{a}$ & $4,3 \mathrm{a}$ \\
100 & $1,8 \mathrm{a}$ & $3,9 \mathrm{a}$ & $4,7 \mathrm{a}$ & $5,1 \mathrm{a}$ \\
\hline BNT $_{(0,05)}$ & 0,23 & 0,74 & 0,92 & 0,90 \\
\hline
\end{tabular}

Keterangan: Angka yang diikuti oleh huruf yang sama tidak berbeda nyata dengan uji BNT pada taraf nyata $5 \%$; MST $=$ minggu setelah tanam.

Tabel 6. Pengaruh pemupukan nitrogen jangka panjang terhadap jumlah anakan maksimum per rumpun dan bobot kering brangkasan.

\begin{tabular}{|c|c|c|}
\hline $\begin{array}{l}\text { Pemupukan Nitrogen } \\
\left(\mathrm{kg} \mathrm{N} \mathrm{ha}^{-1}\right)\end{array}$ & $\begin{array}{l}\text { Jumlah Anakan Maksimum } \\
\text { (anakan per rumpun) }\end{array}$ & $\begin{array}{l}\text { Bobot Kering Berangkasan } \\
\qquad\left(\mathrm{g} \mathrm{m}^{-2}\right)\end{array}$ \\
\hline 0 & $3,6 \quad b$ & 7,2 \\
\hline 50 & $4,4 \quad a b$ & 10,6 a \\
\hline 100 & $5,2 \quad \mathrm{a}$ & 12,2 a \\
\hline $\operatorname{BNT}_{(0,05)}$ & 0,80 & 2,36 \\
\hline
\end{tabular}

Keterangan: Angka yang diikuti oleh huruf yang sama tidak berbeda nyata dengan uji BNT pada taraf nyata $5 \% ;$ MST = minggu setelah tanam. 
pemupukan nitrogen dosis $50 \mathrm{~kg} \mathrm{~N}$ ha $^{-1}$ tidak berbeda dengan $0 \mathrm{~kg} \mathrm{~N} \mathrm{ha}^{-1}$. Hal ini juga terjadi pada produksi gabah per hektar, pemupukan nitrogen dosis $100 \mathrm{~kg} \mathrm{~N}$ $\mathrm{ha}^{-1}$ mampu mempengaruhi produksi gabah per hektar lebih baik dibandingkan dengan $50 \mathrm{~kg} \mathrm{~N} \mathrm{ha}^{-1}$, tetapi pemupukan nitrogen dosis $50 \mathrm{~kg} \mathrm{~N}^{-1}$ tidak berbeda dengan $0 \mathrm{~kg} \mathrm{~N} \mathrm{ha-1}$.

Tabel 7. Pengaruh sistem olah tanah jangka panjang terhadap bobot kering berangkasan.

\begin{tabular}{cc}
\hline Sistem Olah Tanah & $\begin{array}{c}\text { Bobot Kering Berangkasan } \\
\left(\mathrm{g} \mathrm{m}^{-2}\right)\end{array}$ \\
\hline OTI & 11,1 a \\
OTM & 10,9 a \\
TOT & $7,90 \quad$ b \\
\hline BNT $_{(0,05)}$ & 2,36 \\
\hline
\end{tabular}

Keterangan: Angka yang diikuti oleh huruf yang sama tidak berbeda nyata dengan uji BNT pada taraf nyata $5 \%$; MST = minggu setelah tanam. OTI = Olah Tanah Intensif, OTM $=$ Olah Tanah Minimum, TOT $=$ Tanpa Olah Tanah.
Pemupukan nitrogen merupakan salah satu unsur hara makro yang diperlukan bagi pertumbuhan tanaman sehingga kebutuhan unsur hara bagi tanaman dapat terpenuhi. Menurut pendapat Warisno (1998), persediaan unsur hara yang cukup pada setiap fase pertumbuhan merupakan persyaratan utama untuk mendapatkan pertumbuhan dan hasil yang optimum. Hal ini didukung oleh penelitian Setiawan dkk. (2009) menunjukan bahwa rata-rata tinggi tanaman yang diberi dosis pupuk NPK $150 \%$ (Urea $450 \mathrm{~kg} \mathrm{ha}^{-1}$, SP-36 $225 \mathrm{~kg} \mathrm{ha}^{-1}$, dan $\mathrm{KCl}$ $150 \mathrm{~kg} \mathrm{ha}^{-1}$ memiliki rata-rata pengaruh tertinggi dan rata-rata terendah yaitu pada perlakuan tanpa pemupukan. Data tinggi tanaman yang tertinggi pada pemupukan NPK $150 \%$ yaitu $80,09 \mathrm{~cm}$.

Suwardjono (2004) yang dikutip dalam Indria (2005), menyatakan bahwa stuktur tanah yang baik menjadikan perakaran berkembang dengan baik sehingga semakin luas bidang serapan terhadap unsur hara. Selain itu padi gogo merupakan tanaman dengan perakaran dangkal, sehingga pada lapisan top soil tanah untuk sistem olah tanah intensif lebih gembur sehingga akar tanaman lebih mudah untuk berkembang. Sedangkan top soil pada tanpa olah tanah lebih padat daripada olah tanah intensif.

Tabel 8. Pengaruh pemupukan nitrogen jangka panjang terhadap jumlah anakan produktif, jumlah gabah total per rumpun, dan jumlah gabah isi per rumpun.

\begin{tabular}{ccccc}
\hline $\begin{array}{c}\text { Pemupukan } \\
\text { Nitrogen } \\
\left(\mathrm{kg} \mathrm{N} \mathrm{ha}^{-1}\right)\end{array}$ & $\begin{array}{c}\text { Jumlah Anakan } \\
\text { Produktif } \\
\text { (jumlah/rumpun) }\end{array}$ & $\begin{array}{c}\text { Jumlah Gabah Total } \\
\text { Per Rumpun (butir/rumpun) }\end{array}$ & \multirow{2}{*}{$\begin{array}{c}\text { Jumlah Gabah Isi } \\
\text { Per Rumpun } \\
\text { (butir/rumpun) }\end{array}$} \\
\cline { 3 - 4 } & $3 \mathrm{~b}$ & $2,13 \mathrm{c}$ & 423 & $145 \mathrm{~b}$ \\
\hline 0 & $4 \mathrm{a}$ & $2,23 \mathrm{~b}$ & 612 & $187 \mathrm{~b}$ \\
50 & $5 \mathrm{a}$ & $2,32 \mathrm{a}$ & 839 & $336 \mathrm{a}$ \\
\hline BNT $_{(0,05)}$ & 0,86 & 0,04 & & 87,27 \\
\hline
\end{tabular}

Keterangan: Angka yang diikuti oleh huruf yang sama tidak berbeda nyata dengan uji BNT pada taraf nyata $5 \%$; MST = minggu setelah tanam.

Tabe1 9. Pengaruh pemupukan nitrogen jangka panjang terhadap jumlah gabah hampa per rumpun, bobot 100 butir, dan bobot gabah per rumpun.

\begin{tabular}{cccc}
\hline $\begin{array}{c}\text { Pemupukan Nitrogen } \\
\left(\mathrm{kg} \mathrm{N} \mathrm{ha}^{-1}\right)\end{array}$ & $\begin{array}{c}\text { Jumlah Gabah Hampa Per } \\
\text { Rumpun (butir/rumpun) }\end{array}$ & $\begin{array}{c}\text { Bobot 100 Butir } \\
(\mathrm{g})\end{array}$ & $\begin{array}{c}\text { Bobot Gabah per } \\
\text { Rumpun }(\mathrm{g})\end{array}$ \\
\hline 0 & $290 \mathrm{c}$ & $2,9 \mathrm{ab}$ & $6,6 \mathrm{~b}$ \\
50 & $442 \mathrm{~b}$ & $2,9 \mathrm{~b}$ & $6,9 \mathrm{~b}$ \\
100 & $537 \mathrm{a}$ & $3,2 \mathrm{a}$ & $11,7 \mathrm{a}$ \\
\hline BNT $_{(0,05)}$ & 66,50 & 0,20 & 2,22 \\
\hline
\end{tabular}

Keterangan: Angka yang diikuti oleh huruf yang sama tidak berbeda nyata dengan uji BNT pada taraf nyata $5 \%$. 
Tabel 11. Pengaruh pemupukan nitrogen jangka panjang terhadap produksi gabah per petak panen dan produksi gabah per hektar.

\begin{tabular}{ccc}
\hline $\begin{array}{c}\text { Pemupukan Nitrogen } \\
\left(\mathrm{kg} \mathrm{N} \mathrm{ha}^{-1}\right)\end{array}$ & $\begin{array}{c}\text { Produksi Gabah } \\
\left(\mathrm{g} \mathrm{m}^{-2}\right)\end{array}$ & $\begin{array}{c}\text { Produksi Gabah Per Hektar } \\
(\text { ton ha }\end{array}$ \\
\hline 0 & $86,6 \mathrm{~b}$ & $0,9 \mathrm{~b}$ \\
50 & $95,4 \mathrm{~b}$ & $1,0 \mathrm{~b}$ \\
100 & $157,2 \mathrm{a}$ & $1,6 \mathrm{a}$ \\
\hline $\mathrm{BNT}_{(0,05)}$ & 31,91 & 0,31 \\
\hline Keterangan: Angka yang diikuti oleh huruf yang sama tidak berbeda nyata dengan uji BNT pada taraf \\
nyata 5\%; MST = minggu setelah tanam.
\end{tabular}

Penelitian Pirngadi dkk. (2007), yang menunjukan bahwa jumlah anakan yang paling banyak dicapai pada dosis pemupukan $135 \mathrm{~kg} \mathrm{~N} \mathrm{ha}^{-1}$ sedangkan yang paling rendah pada pemupukan $0 \mathrm{~kg} \mathrm{~N}^{-1}$. Darwis (1979) menyatakan bahwa pembentukan anakan hampir selalu sebanding dengan ketersediaan nitrogen dalam tanah selama pembentukan anakan.

Menurut Minardi (2002) bahwa pemberian pupuk NPK dapat memberikan tambahan unsur NPK tersedia dalam tanah yang berpengaruh pada pertumbuhan tanaman. Menurut pendapat Ramadhan (2014), mengatakan bahwa kombinasi pemupukan sangat mempengaruhi pertumbuhan tanaman padi.

Hasil penelitian Pirngadi dkk., (2007) menunjukan bahwa pemupukan nitrogen mampu meningkatkan jumlah anakan produktif. Jumlah anakan produktif tertinggi 7 malai per rumpun dicapai oleh pemupukan $90 \mathrm{~kg} \mathrm{~N}^{-1}{ }^{-1}$ tidak berbeda nyata dengan perlakuan $135 \mathrm{~kg} \mathrm{~N} \mathrm{ha}^{-1}$ tetapi berbeda nyata dengan perlakuan lainnya. Menurut pendapat Poulton, dkk (1989) bahwa unsur hara menjadi komponen penting bagi tanaman khususnya unsur hara makro seperti N, P, dan $\mathrm{K}$ dalam jumlah yang cukup dan berimbang karena dapat mempengaruhi petumbuhan tanaman baik pada fase pertumbuhan vegetatif maupun fase generatif.

Pemupukan nitrogen meningkatkan persentase gabah isi. Persentase gabah isi tertinggi sebesar $75,06 \%$ dicapai oleh pemupukan $90 \mathrm{~kg} \mathrm{~N} \mathrm{ha}^{-1}$, tidak berbeda nyata dengan pemupukan $135 \mathrm{~kg} \mathrm{~N} \mathrm{ha}^{-1}$, tetapi berbeda dengan perlakuan lainnya (Pirngadi dkk., 2007). Menurut Sukristiyonubowo dan Tuherkih (2009), menyatakan bahwa hara dari pupuk NPK dimanfaatkan tanaman untuk pertumbuhan tanaman sama baiknya dengan hara yang berasal dari pupuk tunggal Urea, SP-36, dan KCl. Hal ini menunjukan bahwa pupuk yang diberikan mampu meningkatkan pertumbuhan tanaman pada fase vegetatif maupun fase generatif. Unsur $\mathrm{N}, \mathrm{P}$, dan $\mathrm{K}$ dalam perlakuan pupuk diserap oleh tanaman dan digunakan untuk proses metabolisme di dalam tanaman.

\section{KESIMPULAN}

Adapun kesimpulan dari penelitian ini yaitu pemupukan nitrogen dengan dosis $100 \mathrm{~kg} \mathrm{~N} \mathrm{ha}^{-1}$ meningkatkan pertumbuhan dibandingkan tanpa pemupukan nitrogen tetapi tidak berbeda dengan pemupukan $50 \mathrm{~kg} \mathrm{~N} \mathrm{ha}^{-1}$. Pemupukan nitrogen dengan dosis $100 \mathrm{~kg} \mathrm{~N} \mathrm{ha}^{-1}$ meningkatkan produksi padi gogo

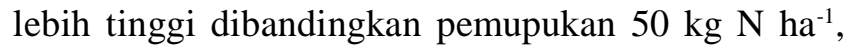
sedangkan pemupukan $50 \mathrm{~kg} \mathrm{~N} \mathrm{ha}^{-1}$ tidak berbeda dengan tanpa pemupukan nitrogen.

Sistem Olah Tanah Intensif mampu meningkatkan tinggi tanaman, dan bobot kering berangkasan lebih tinggi dibandingkan dengan Olah Tanah Konservasi, sedangkan sistem olah tanah memberikan hasil yang sama terhadap komponen hasil. Interaksi antara pemupukan nitrogen dan sistem olah tanah terjadi pada variabel pengamatan tinggi tanaman, sedangkan terhadap komponen hasil tidak berpengaruh.

\section{DAFTAR PUSTAKA}

Abdullah, B. 2003. Status Perkembangan Pemuliaan Padi Type Baru. Puslitbangtan, Badan Litbang Pertanian. 11p.

Buckman, H.O. dan N.C. Brady, 1992. Ilmu Tanah. Jakarta. Bharata Karya Aksara.

Darwis, S.N. 1979. Agronomi Tanaman Padi. Lembaga Pusat Penelitian Pertanian. Perwakilan Padang. Jilid I. 86 hlm.

Indria, A. T. 2005. Pengaruh Sistem Olah Tanah dan Pemberian Berbagai Macam Bahan Organik terhadap Pertumbuhan dan Hasil Kacang Tanah (Arachis hypogea L.). Skripsi. Universitas Sebelas Maret. Surakarta.

Minardi, S. 2002. Kajian komposisi pupuk NPK terhadap hasil beberapa varietas tanaman buncis tegak 
(Phaseolus vulgaris L.) di tanah Alfisol. Sains Tanah. 2 (1):18-24 hlm.

Pirngadi, K., H.M. Toha., dan B. Nuryanto. 2007. Pengaruh pemupukan $\mathrm{N}$ pada pertumbuhan dan hasil padi gogo di Dataran Sedang, Balai Besar Penelitian Tanaman Padi. J.Apresiasi Hasil Penelitian Padi. 325-338 hlm.

Poulton, J.E., J.T. Romeo, dan E.E. Conn. 1989. Plant Nitrogen Metabolism. Recent Advances in Phytochemistry. Vol 23. New York. Plenum Press.

Pulung, M.A. 2005. Kesuburan Tanah. Universitas Lampung. Bandar Lampung. $287 \mathrm{hlm}$.

Ramadhan, F. 2014. Parameter Genetik Beberapa Varietas Padi (Oryza sativa L.) pada Kondisi Media Berbeda. Skripsi. Universitas Syiah Kuala. Banda Aceh.

Sanchez, P.A. 1992. Sifat dan Pengelolaan Tanah Tropika (Buku 2). Terjemahan : Properties and Management in The Tropics. ITB. Bandung.
Setiawan, A., J. Moenandir, dan A.Nugroho. 2009. Pengaruh pemupukan N, P, K pada pertumbuhan dan hasil padi (Oryza sativa L.). Kepras Jurnal. 5-6 hlm.

Sukristiyonubowo dan E.Tuherkih. 2009. Rice production in teraced paddy field systems. J. Penelitian dan Pengembangan Pertanian. Departemen Pertanian. $7 \mathrm{hlm}$.

Toha, H.M. 2002. Pengembangan Padi Gogo di Lahan Kering Beriklim Basah. Puslitbangtan, Badan Litbang Pertanian. 26p.

Utomo, M. 1995. Kekerasan tanah dan serapan hara tanaman jagung pada olah tanah konservasi jangka panjang. J.Tanah Trop. 1:1-7.

Warisno. 1998. Jagung Hibrida. Kanisius. Yogyakarta. $83 \mathrm{hlm}$.

Wibowo, R. 2000. Pertanian dan Pangan. Pustaka Sinar Harapan. Jakarta. 